\title{
Synthesis, Characterization, and Photochemical Properties of a New Square Mn(I)-Ru(II) Complex Using Pyrazine as Bridge Ligand
}

\author{
Inara de Aguiar, ${ }^{1}$ Simone D. Inglez, ${ }^{2}$ Antonio Claudio Tedesco, ${ }^{3}$ and Rose Maria Carlos ${ }^{1}$ \\ ${ }^{1}$ Departamento de Química, Universidade Federal de São Carlos, CP 676, 13565-905 São Carlos, SP, Brazil \\ ${ }^{2}$ Faculdade de Ciências Exatas e Tecnologia, Universidade Federal da Grande Dourados, CP 533, 79804-970 Dourados, MS, Brazil \\ ${ }^{3}$ Departamento de Ciências Farmacêuticas, Faculdade de Filosofia, Ciências e Letras de Ribeirão Preto, Universidade de São Paulo, \\ 14040-901 Ribeirão Preto, SP, Brazil
}

Correspondence should be addressed to Rose Maria Carlos; rosem@ufscar.br

Received 1 July 2012; Revised 19 September 2012; Accepted 8 October 2012

Academic Editor: R. P. S. Chakradhar

Copyright (C) 2013 Inara de Aguiar et al. This is an open access article distributed under the Creative Commons Attribution License, which permits unrestricted use, distribution, and reproduction in any medium, provided the original work is properly cited.

\begin{abstract}
The photochemical properties of the complexes cis, fac- $\left[\mathrm{Ru}(\mathrm{phen})_{2}(\mathrm{pz})_{2}-\mathrm{Mn}(\mathrm{CO})_{3} \mathrm{Br}\right]_{2}{ }^{4+}(\mathbf{I})$, cis- $\left[\mathrm{Ru}(\mathrm{phen}) 2(\mathrm{pz})_{2}\right]^{2+}(\mathbf{I I})$, and fac- $\mathrm{Mn}(\mathrm{CO})_{3}(\mathrm{pz})_{2} \mathrm{Br}(\mathrm{III})$ where phen is phenanthroline and $\mathrm{pz}$ is pyrazine in acetonitrile solution are reported. The three complexes were characterized using ${ }^{1} \mathrm{H}$ NMR, UV-vis and FTIR spectroscopy and electrochemical (cyclic voltammetry and spectroelectrochemical) techniques. The complexes show intense absorption in the visible region assigned to the population of MLCT excited states. The absorption spectrum of $\mathbf{I}$ is the sum of the spectra of the mononuclear species II and III, and the two oxidation potentials at +1.10 and $+1.56 \mathrm{~V}$ versus $\mathrm{Ag} / \mathrm{AGCl}$ observed in $\mathrm{I}$ are ascribed to the different coordination environments of metal centers. The photolysis in the acetonitrile solution resulted in the $\mathrm{pz}$ dissociation to give the monoacetonitrile complexes for I, II, and III, respectively.
\end{abstract}

\section{Introduction}

The investigation of spectroscopic, electrochemical, and photochemical properties of manganese compounds has attracted much attention due to the potential application of these compounds in the development of the supramolecular system which may work photochemically for clean energy sources in renewable solar fuels $[1,2]$. Most of current research is being focused on the covalent coupling of a photoactive $\mathrm{Ru}(\mathrm{II})$ polypyridinic complex to a high-valence mono- and/or multinuclear $\mu$-oxo bridged manganese complexes. Herein, we wish to report a novel, square pyrazine donor-acceptor complex, composed of a triscarbonyl manganese complex linked to two ruthenium(II) phenanthroline complexes via two pyrazine bridge ligands. Our approach, introducing three good $\pi$ acceptor (CO) and one good $\pi$ donor $\left(\mathrm{Br}^{-}\right)$ligand, was chosen because of the abilities of these ligands to accept and donate electronic density to metal centers and in this way to stabilize the high oxidation states that the manganese center may acquire during the photoinduced electron transfer reaction. For this reason, in this work the photochemical stability of the complexes was studied.

\section{Experimental}

2.1. General. All synthesis and electrochemical and spectroscopic experiments were carried out under purified $\mathrm{N}_{2}$ atmosphere, using Schlenk techniques. $\mathrm{RuCl}_{3} \cdot x \mathrm{H}_{2} \mathrm{O}, 1,10^{\prime}$-phenanthroline (phen), pyrazine (pz), and lithium chloride were from Aldrich; tetrabutylammonium hexafluorophosphate $\left(\mathrm{TBAPF}_{6}\right)$ and bromide pentacarbonyl manganese from Strem. HPLC grade acetonitrile and dichloromethane were distilled prior to use. The solutions were carefully handled in the dark before the experiments were 


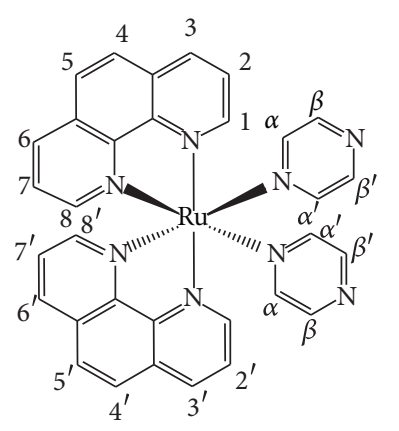

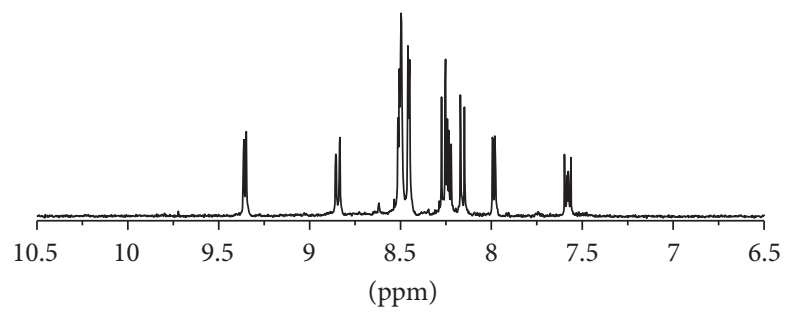

(a)

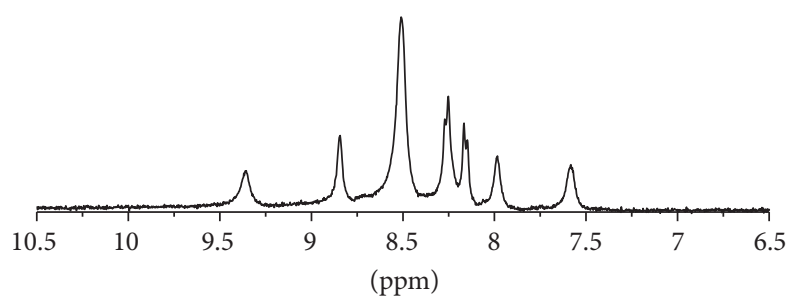

(b)

FIGURE 1: ${ }^{1} \mathrm{H}$ NMR spectra in $\mathrm{CD}_{3} \mathrm{CN}$ of the aromatic region to the complex II (a) and complex I (b).

performed. The complexes cis- $\left[\mathrm{Ru}(\text { phen })_{2} \mathrm{Cl}_{2}\right] \cdot 2 \mathrm{H}_{2} \mathrm{O}$ [3], cis$\left[\mathrm{Ru}(\text { phen })_{2} \mathrm{CO}_{3}\right] \cdot 2 \mathrm{H}_{2} \mathrm{O} \quad[4]$, cis- $\left[\mathrm{Ru}(\text { phen })_{2}\left(\mathrm{H}_{2} \mathrm{O}\right)_{2}\right]\left(\mathrm{PF}_{6}\right)_{2}$ [5], and $\left[\mathrm{Mn}(\mathrm{CO})_{3}(\mathrm{pz})_{2} \mathrm{Br}\right]$ [6] were prepared by the literature routes. FTIR spectra were measured in $\mathrm{CaF}_{2}$ windows in $\mathrm{CH}_{2} \mathrm{Cl}_{2}$ solution on a Bomem-Michelson 102 spectrometer in the $4000-1000 \mathrm{~cm}^{-1}$ region. UV-visible spectra were recorded on an HP-8453 A (Diode array) spectrophotometer. NMR spectra were recorded using a Bruker DRX400 spectrometer. All chemical shifts $(\delta)$ are given in ppm units with reference to the hydrogen signal of the methyl group of tetramethylsilane (TMS) as internal standard. Monochromatic irradiations at $350 \mathrm{~nm}$ and $420 \mathrm{~nm}$ were generated using an RMR-600 model Rayonet Photochemical reactor using RMR-3500 and RMR-4200 lamps, respectively. The continuous photolysis experiments were followed by UV-vis. Time-resolved optical spectra were obtained using a laser flash-photolysis apparatus containing a Continuum Q-switched Nd:YAG laser (Continuum, Santa Clara, CA) with excitation provided by the third harmonic at $\lambda 355 \mathrm{~nm}$. Cyclic voltammetry was performed using an $\mu$ Autolab Type III potentiostat. Voltammograms were obtained in $\mathrm{CH}_{3} \mathrm{CN}\left(1 \mathrm{mM} \mathrm{TBPF}_{6}\right)$ at $22^{\circ} \mathrm{C}$ in a lightprotected voltammetric cell with a platinum cylinder disc for both the working and the auxiliary electrodes. A silver wire

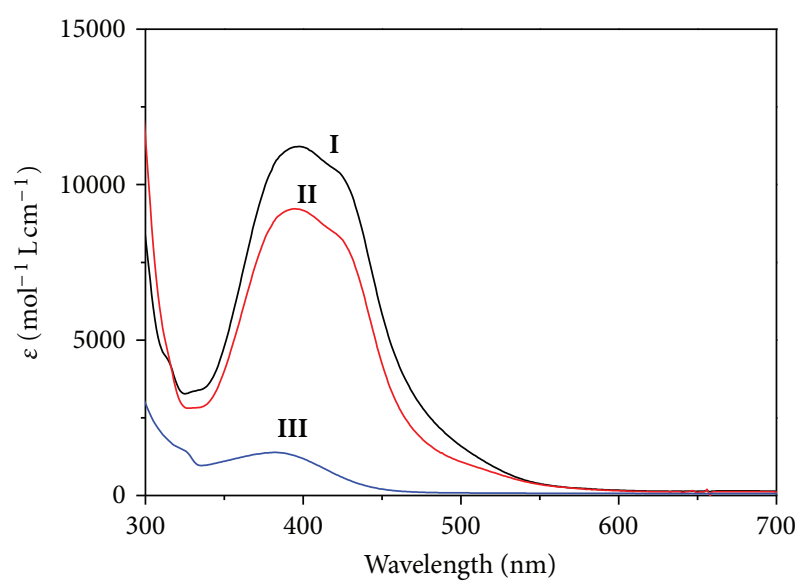

FIgURE 2: Electronic spectra in $\mathrm{CH}_{3} \mathrm{CN}$ solution of (I) cis, fac$\left[\mathrm{Ru}(\mathrm{phen})_{2}(\mathrm{pz})_{2}-\mathrm{Mn}(\mathrm{CO})_{3} \mathrm{Br}\right]_{2}$, (II) cis- $\left[\mathrm{Ru}(\mathrm{phen})_{2}(\mathrm{pz})_{2}\right]$, (III) fac$\left[\mathrm{Mn}(\mathrm{CO})_{3}(\mathrm{pz})_{2} \mathrm{Br}\right]$.

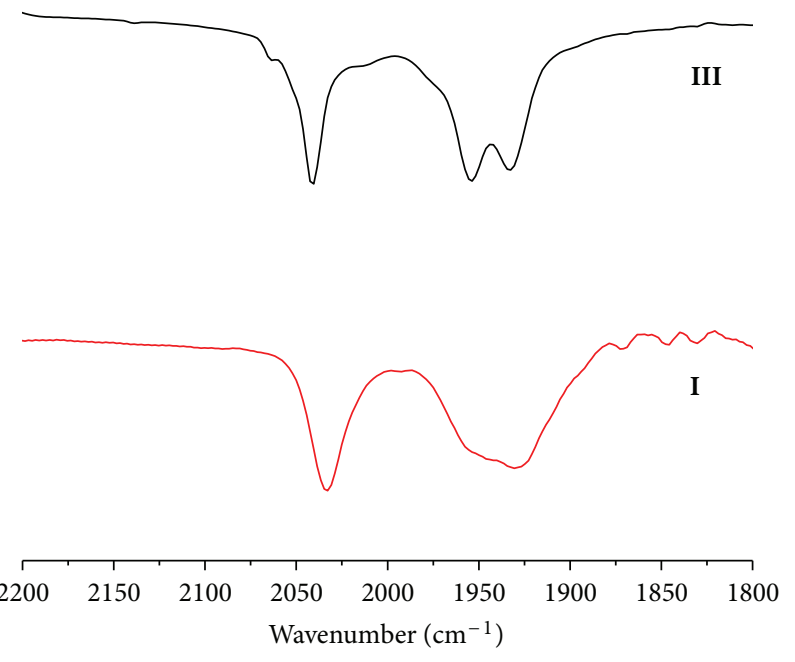

FIGURE 3: FTIR spectra of complexes III (black line) and I (red line) in $\mathrm{CH}_{2} \mathrm{Cl}_{2}$ at room temperature, with $\mathrm{CaF}_{2}$ window.

coated with silver chloride was used as reference electrode, connected to the bulk of the solution by a Luggin capillary filled with the same solvent and electrolyte. Solutions were deoxygenated with a stream of $\mathrm{N}_{2}$ and maintained under a positive pressure of $\mathrm{N}_{2}$ during the measurements. The concentration of the complexes was kept always at $1 \mathrm{mM}$.

\subsection{Synthesis}

2.2.1. cis, fac- $\left[R u(p h e n)_{2}(p z)_{2}-\mathrm{Mn}(\mathrm{CO})_{3} B r\right]_{2}\left(\mathrm{PF}_{6}\right)_{4}(\mathbf{I})$. $\mathrm{Mn}(\mathrm{CO})_{5} \mathrm{Br}(74 \mathrm{mg}, 0.27 \mathrm{mmol})$ was dissolved in degassed acetone $(50 \mathrm{~mL})$, and the complex cis- $\left[\mathrm{Ru}(\mathrm{phen})_{2}(\mathrm{pz})_{2}\right]$ $(250 \mathrm{mg}, 0.27 \mathrm{mmol})$ was added. It was stirred under dark for 12 hours at room temperature. The orange precipitate formed was filtrated and dried under vacuum. Yield $=80 \%$.

2.2.2. cis- $\left[R u(p h e n)_{2}(p z)_{2}\right]\left(P_{6}\right)_{2}(\mathrm{II}) .\left[\mathrm{Ru}(\text { phen })_{2} \mathrm{Cl}_{2}\right] \cdot 2 \mathrm{H}_{2} \mathrm{O}$ (200 $\mathrm{mg}, 0.35 \mathrm{mmol}$ ) and pyrazine $(282 \mathrm{mg}, 3.52 \mathrm{mmol}$ ) were 

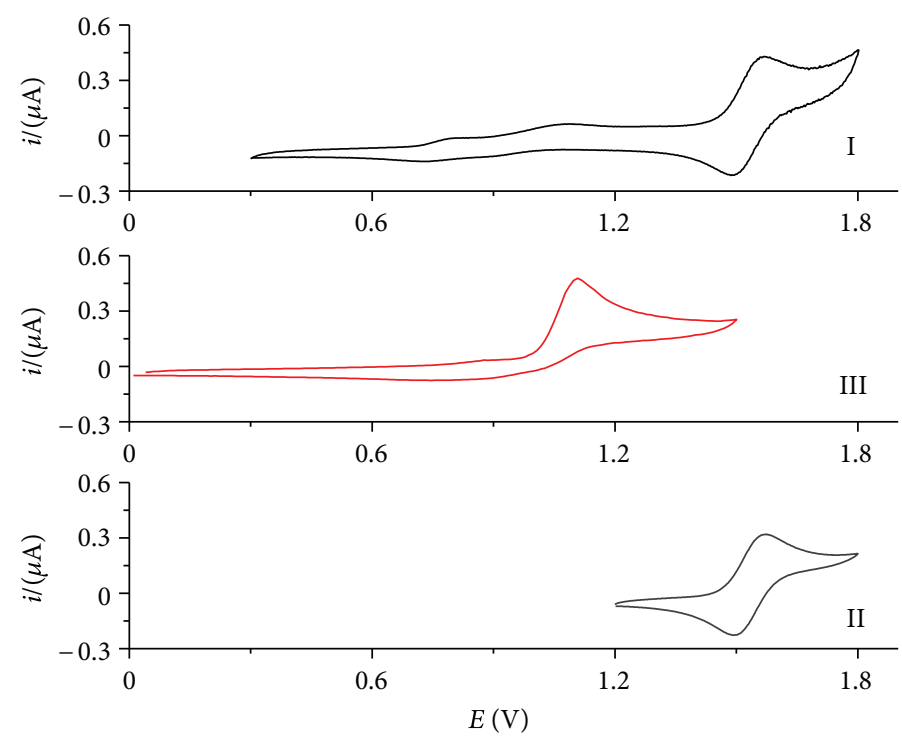

FIgURe 4: Cyclic voltammograms of complexes I, II and III ( $1 \mathrm{mM}), \mathrm{TBPF}_{6}(0.1 \mathrm{M})$ versus $\mathrm{Ag} / \mathrm{AgCl}$, scan rate $100 \mathrm{mV} / \mathrm{s}, 25^{\circ} \mathrm{C}$, in $\mathrm{CH}{ }_{3} \mathrm{CN}$.

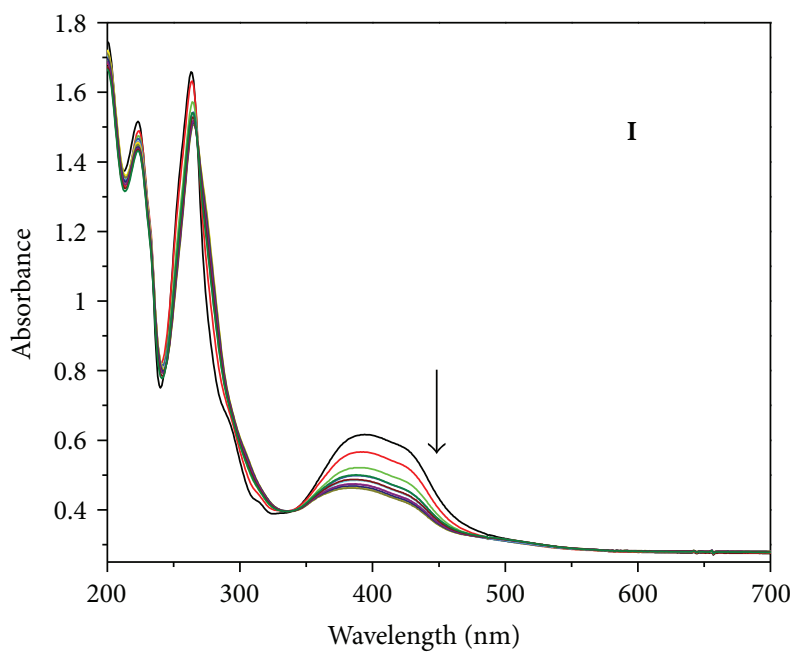

(a)

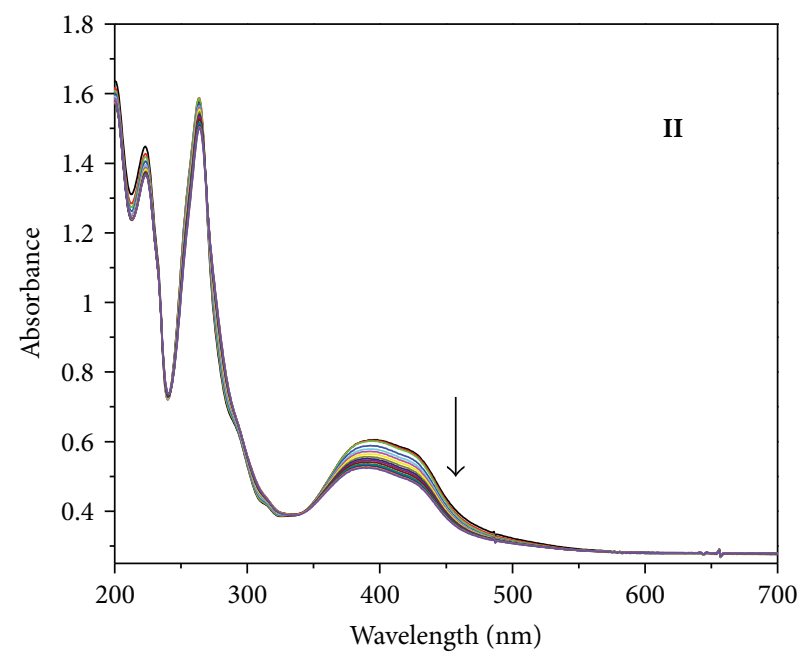

(b)

FIGURE 5: Spectroelectrochemical of complex I ( $1.5 \mathrm{mM}^{\text {in } \mathrm{CH}_{3} \mathrm{CN} ; 0.1 \mathrm{M} \text { TBAPF}}$ ) and complex II $\left(1.5{\mathrm{mM} \mathrm{in} \mathrm{CH}_{3} \mathrm{CN}_{6} 0.1 \mathrm{M} \text { TBAPF}}_{6}\right)$ in an OTTLE cell, oxidation $E_{\text {applied }}=1.5 \mathrm{~V}$ versus $\mathrm{Ag} / \mathrm{AgCl}$.

refluxed in a $1: 1 \mathrm{EtOH} / \mathrm{H}_{2} \mathrm{O}$ solution for 6 hours. Upon cooling to room temperature, a saturated solution of ammonium hexafluorophosphate was added to the solution to precipitate an orange product, which was isolated by filtration. The orange solid was recrystallized using acetone/ether. Yield: $70 \%$.

2.2.3. fac- $\left[\mathrm{Mn}(\mathrm{CO})_{3}(p z)_{2} \mathrm{Br}\right](\mathrm{III}) . \mathrm{Mn}(\mathrm{CO})_{5} \mathrm{Br} \quad(200 \mathrm{mg}$, $0.73 \mathrm{mmol}$ ) was dissolved in degassed $\mathrm{CH}_{2} \mathrm{Cl}_{2}(50 \mathrm{~mL})$ and pyrazine $(117 \mathrm{mg}, 1.45 \mathrm{mmol})$. It was stirred under dark for 12 hours at room temperature. The yellow precipitate formed was filtrate and dried under vacuum. Yield: $80 \%$.

\section{Results and Discussion}

The square complex was synthesized in a manner similar to a previously published procedure [1], starting from cis- $\left[\mathrm{Ru}(\mathrm{phen})_{2}(\mathrm{pz})_{2}\right]^{2+}$ and considering the complex $\mathrm{Mn}(\mathrm{CO})_{5} \mathrm{Br}$ as a ligand (Scheme 1 ).

The ${ }^{1} \mathrm{H}$ NMR spectral data for the ligands and complexes in $\mathrm{CD}_{3} \mathrm{CN}$ are listed in Table 1 using the numbering scheme as represented for complex II as follow. The signals of the complex I were assigned by comparison and analysis of the precursor $\mathrm{Ru}(\mathrm{phen})_{2} \mathrm{Cl}_{2}$ and the free pyrazine. In the complex I, the phenanthroline protons appeared as eight 

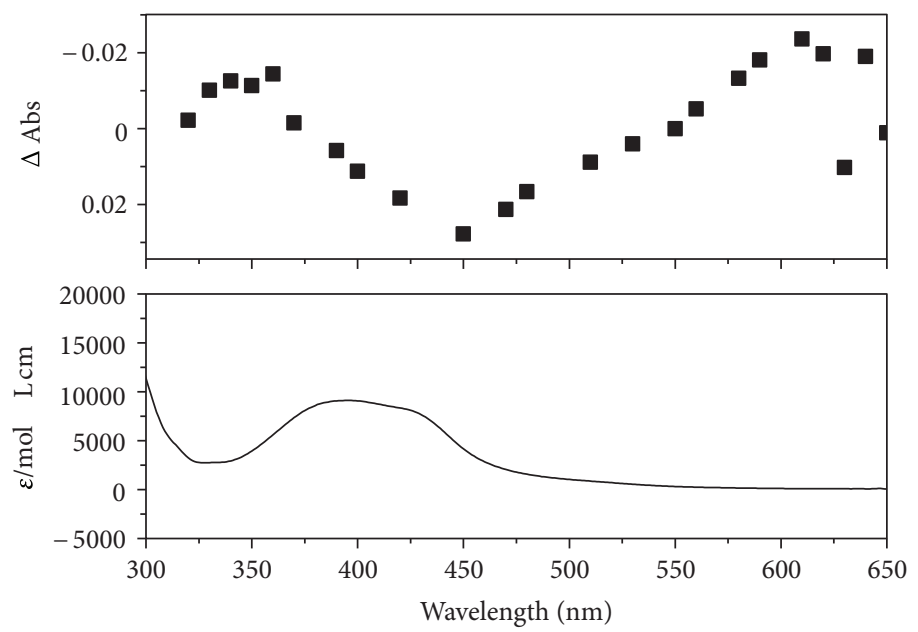

FIGURE 6: Transient (upper) and experimental (low) absorption spectra of complex I in acetonitrile.

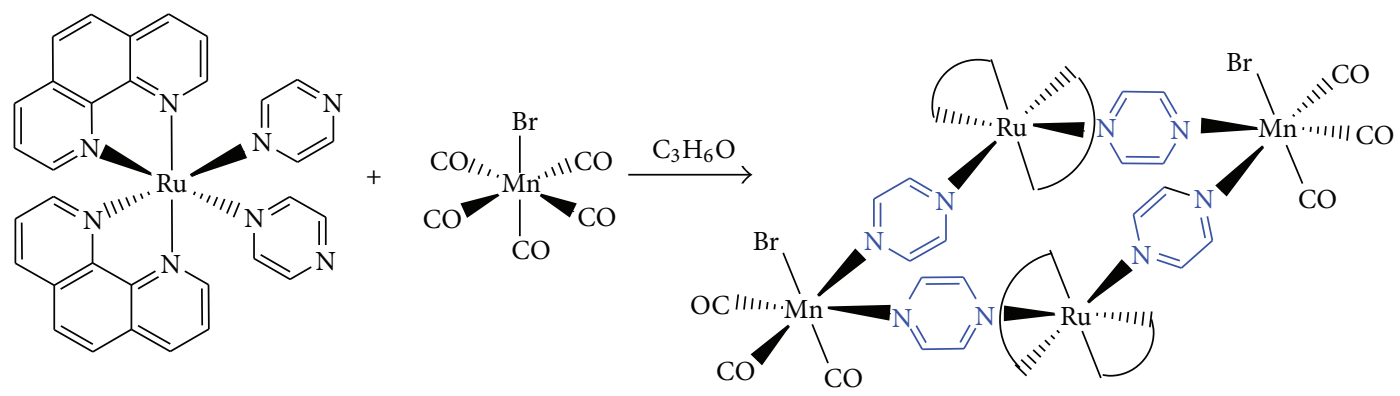

SCHEME 1: Synthesis of square complex I.

TABLE $1:{ }^{1} \mathrm{H}$ NMR spectral data of complexes I and II in $\mathrm{CD}_{3} \mathrm{CN}$.

\begin{tabular}{lcc}
\hline$\delta_{\mathrm{H}}(\mathrm{ppm})$ & Complex II & Complex I \\
\hline Proton type & & \\
$\mathrm{H}_{1} \mathrm{H}_{1^{\prime}}$ & $9.35(2 \mathrm{H}, \mathrm{d})$ & $9.35(4 \mathrm{H})$ \\
$\mathrm{H}_{2} \mathrm{H}_{2^{\prime}}$ & $8.25(4 \mathrm{H}, \mathrm{m})$ & $8.26(8 \mathrm{H})$ \\
$\mathrm{H}_{3} \mathrm{H}_{3^{\prime}}$ & $8.84(2 \mathrm{H}, \mathrm{d})$ & $8.84(4 \mathrm{H})$ \\
$\mathrm{H}_{4} \mathrm{H}_{4^{\prime}}$ & $8.25(4 \mathrm{H}, \mathrm{m})$ & $8.26(8 \mathrm{H})$ \\
$\mathrm{H}_{5} \mathrm{H}_{5^{\prime}}$ & $8.14(2 \mathrm{H}, \mathrm{d})$ & $8.15(4 \mathrm{H})$ \\
$\mathrm{H}_{6} \mathrm{H}_{6^{\prime}}$ & $8.50(2 \mathrm{H}, \mathrm{d})$ & $8.50(4 \mathrm{H})$ \\
$\mathrm{H}_{7} \mathrm{H}_{7^{\prime}}$ & $7.57(2 \mathrm{H}, \mathrm{m})$ & $7.58(4 \mathrm{H})$ \\
$\mathrm{H}_{8} \mathrm{H}_{8^{\prime}}$ & $7.98(2 \mathrm{H}, \mathrm{dd})$ & $7.98(4 \mathrm{H})$ \\
$\mathrm{H}_{\alpha} \mathrm{H}_{\alpha^{\prime}}$ & $8.49(4 \mathrm{H}, \mathrm{d})$ & $8.50(8 \mathrm{H})$ \\
$\mathrm{H}_{\beta} \mathrm{H}_{\beta^{\prime}}$ & $8.45(4 \mathrm{H}, \mathrm{d})$ & $8.50(8 \mathrm{H})$ \\
\hline
\end{tabular}

signals instead of four signals to the free ligand, as expected for the cis isomer. The two pyrazine $\alpha$ and $\beta$ protons were observed at $8.49(4 \mathrm{H}, \mathrm{d})$ and $8.45(4 \mathrm{H}, \mathrm{d})$. On coordination of $\mathrm{Ru}(\mathrm{II})$ to $\mathrm{Mn}$ (I) (Figure 2, Table 1), the linewidth of all signals were broadened due to the presence of the bromide ion coordinated at the manganese center. The absence of new signals in the whole spectrum, as expected to a triangle complex, suggests the formation of the square complex, which was further confirmed by signals integration [7]. In the
TABLE 2: Electrochemistry properties of complexes I, II, and III in $\mathrm{CH}_{3} \mathrm{CN}$.

\begin{tabular}{lccc}
\hline & $E_{\text {ox }} / E_{\text {red }}, V$ & $\nu \mathrm{CO} \mathrm{cm}^{-1}$ & $\lambda_{\text {máx }}, \mathrm{nm}(\varepsilon)$ \\
\hline Complex I & 1.10 & 2032,1938 & $394(11500) ;$ \\
& $0.79 / 0.73$ & & $442(10400)$ \\
Complex II & $1.56 / 1.49$ & - & $394(9100)$ \\
& & & $425(8000)$ \\
Complex III & 1.10 & $2041,1953,1932$ & $381(2900)$ \\
\hline
\end{tabular}

square complex, all the assignments were done using the same numbering figure as complex II, Figure 1.

3.1. Absorption Properties. The absorption spectra of complexes I, II, and III in $\mathrm{CH}_{3} \mathrm{CN}$ solution are shown in Figure 2. The absorption maximum of $380 \mathrm{~nm}\left(\varepsilon_{\max }=\right.$ $1400 \mathrm{~mol}^{-1} \mathrm{~L} \mathrm{~cm}^{-1}$ ) for III appears as a shoulder on the strong $\pi-\pi^{*}$ absorption bands of the ligands, while the complex II exhibits the intense and broad MLCT absorption $\left(\lambda_{\max }=\right.$ $397 \mathrm{~nm} ; \varepsilon_{\max }=9200 \mathrm{~mol}^{-1} \mathrm{~L} \mathrm{~cm}^{-1}$ ) typical of $\mathrm{Ru}^{\mathrm{II}}$ polypyridine complexes [8]. The absorption spectrum of $\mathbf{I}\left(\lambda_{\text {máx }}=\right.$ $397 \mathrm{~nm} ; \varepsilon_{\text {máx }}=11230 \mathrm{~mol}^{-1} \mathrm{~L} \mathrm{~cm}^{-1}$ ) is consistent with the 


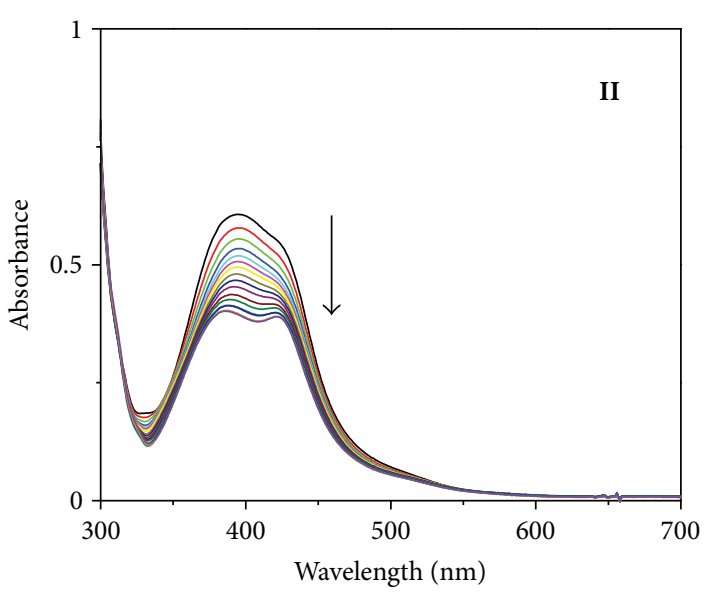

(a)

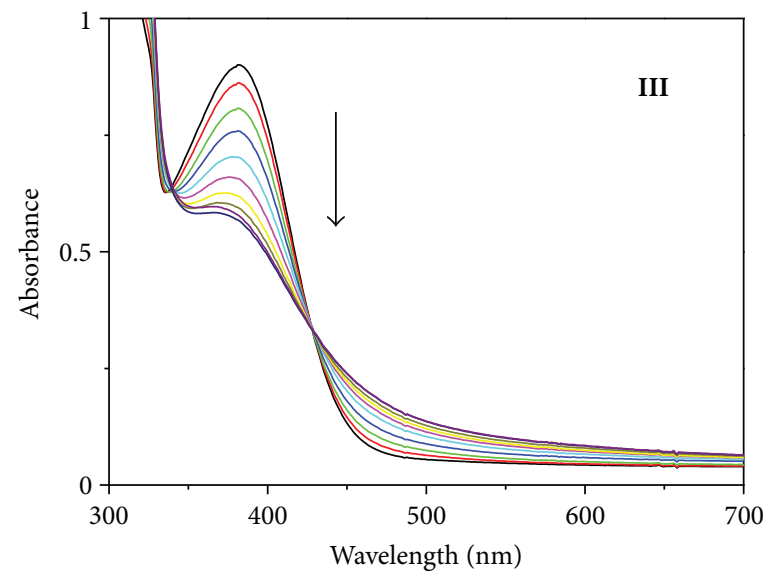

(b)

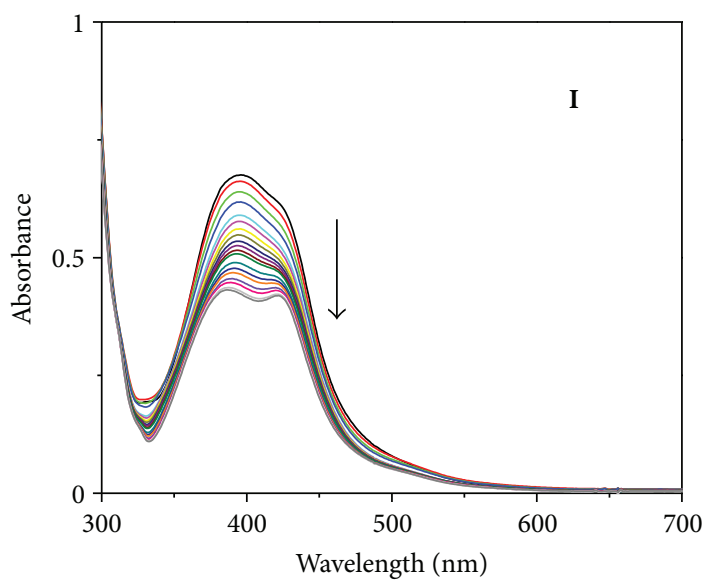

(c)

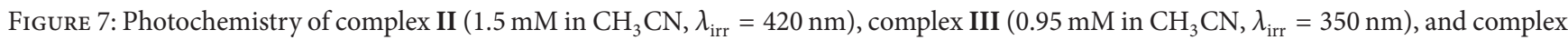
I $\left(1.5 \mathrm{mM}\right.$ in $\left.\mathrm{CH}_{3} \mathrm{CN}, \lambda_{\text {irr }}=420 \mathrm{~nm}\right)$.

superposition of bands characteristics of the corresponding mononuclear complexes. The data for complex I show that the energy of the charge transfer band $\mathrm{Ru}^{\mathrm{II}} \rightarrow \mathrm{L}(394 \mathrm{e}$ $442 \mathrm{~nm}$ ) remains unchanged upon the introduction of $\mathrm{Mn}$ ion into the $\mathrm{Ru}$ complex, whereas it is slightly shifted to shorter wavelength compared to the tris-(phenanthroline) complexes (422 and $446 \mathrm{~nm}$ ) [9], which is characteristic of ligands serving as better $\pi$-acceptors ligands than phen.

The FTIR spectrum of III, shown in Figure 3, exhibitsthree intense $v(\mathrm{CO})$ absorptions at 2041, 1953, and $1932 \mathrm{~cm}^{-1}$ consistent with the facial arrangement of the three COs in the coordination sphere. For complex I, the $v(\mathrm{CO})$ stretching frequency appears as weak and broad bands around 2032 and $1940 \mathrm{~cm}^{-1}$, and the two lower energy bands are overlapped suggesting the attachment of $\mathrm{Mn}(\mathrm{CO})_{3}$ unit into the $\mathrm{Ru}^{\mathrm{II}}$ complex.

3.2. Electrochemistry. The voltammetric data are summarized in Table 2. Figure 4 shows a cyclic voltammogram (scan rate $100 \mathrm{mVs}^{-1}$ ) for a $1 \mathrm{mM}$ solution of the complexes I, II, and III over the range $0-1.8 \mathrm{~V}$ (versus $\mathrm{AG} / \mathrm{AGCl}$ ) in acetonitrile $\left(\mathrm{TBPF}_{6} 1 \mathrm{mM}\right)$.
Complex II exhibits a redox couple at $E_{1 / 2}=1.52 \mathrm{~V}$ $\left(E_{\text {ox }}=1.56 \mathrm{~V}\right.$ and $E_{\text {red }}=1.49 \mathrm{~V}$ versus $\left.\mathrm{Ag} / \mathrm{AgCl}\right)$ of $\mathrm{Ru}^{\mathrm{II} / \mathrm{III}}$ which is more positive than those found to $\left[\mathrm{Ru}(\mathrm{phen})_{3}\right]^{2+}$ [10]. The complex III, on the other hand, displays a shoulder at $0.80 \mathrm{~V}$ corresponding to $\mathrm{Mn}^{\mathrm{I} / \mathrm{II}}$ oxidation followed by an oxidation peak at $1.10 \mathrm{~V}$ attributed to the oxidation of $\mathrm{Mn}^{\mathrm{II}}$ to $\mathrm{Mn}^{\mathrm{III}}$, which is paired with a nonreversible reductive wave at 0.90 due to $\mathrm{Mn}^{\mathrm{III} / \mathrm{II}}$ reduction.

The $\mathrm{Mn}(\mathrm{CO})_{3} \mathrm{Br}$ coordination on the $\mathrm{Ru}(\mathrm{phen})_{2}(\mathrm{pz})_{2}$ did not change the redox potential values of the $\mathrm{Ru}(\mathrm{II})$ metal center. The cyclic voltam ogram of complex I exhibits one irreversible oxidation at $1.10 \mathrm{~V}$ and two redox couple $E_{1 / 2}(1)=0.76 \mathrm{~V}\left(E_{\mathrm{ox}}=0.79 \mathrm{~V}\right.$ and $E_{\text {red }}=0.73 \mathrm{~V}$ versus $\mathrm{Ag} / \mathrm{AgCl})$ and $E_{1 / 2}(2)=1.52 \mathrm{~V}\left(E_{\mathrm{ox}}=1.56 \mathrm{~V}\right.$ and $E_{\text {red }}=$ $1.49 \mathrm{~V}$ versus $\mathrm{Ag} / \mathrm{AgCl})$.

3.3. Spectroelectrochemistry. Insights into the bonding characteristics of the $\mathrm{Ru}(\mathrm{II})$ complexes for complexes I and II were obtained by spectroelectrochemical experiments. For the $\mathrm{Ru}$ (II) complexes, a constant potential $1.5 \mathrm{~V}$ (determined from cyclic voltammetry) was applied and the extent of oxidation to $\mathrm{Ru}$ (III) was monitored by UV-vis spectroscopy 


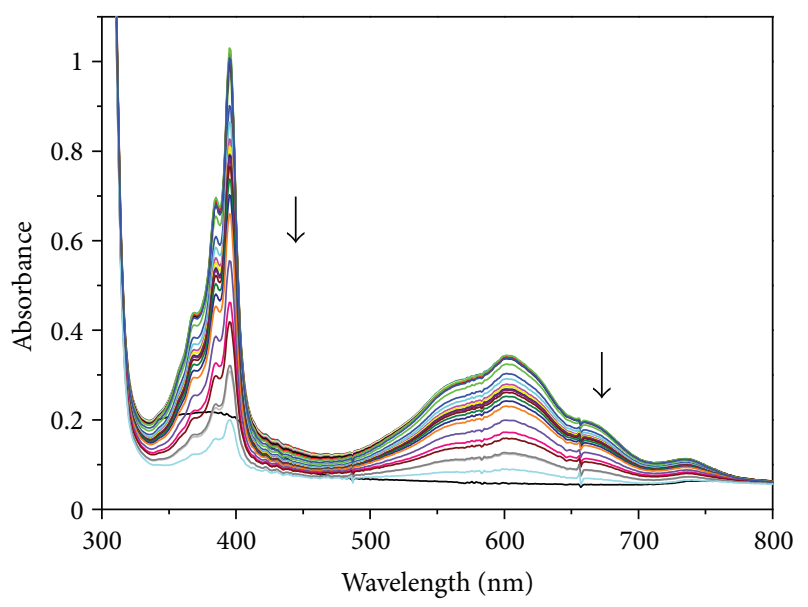

FIGURE 8: Spectral changes accompanying the consume of reduced methyl viologen $\left(\mathrm{MV}^{\bullet+}\right)$, from the thermal reaction $\mathrm{MV}^{\bullet+} \rightarrow$ $\mathrm{MV}^{2+}$ in $\mathrm{H}_{2} \mathrm{O}$, (black line-spectrum of the mixture: complex III and $\mathrm{MV}^{2+}$ before irradiation).

(Figure 5). The spectrum shows the disappearance of the broad absorption band at $400 \mathrm{~nm}$. After $30 \mathrm{~min}$ of oxidative electrolysis, the spectral changes were completed. The oxidative spectroelectrochemistry at $1.5 \mathrm{~V}$ leads to disappearance of the MLCT band indicating that oxidation was a $\mathrm{Ru}^{\mathrm{II} / \mathrm{III}}$ process which is irreversible.

3.4. Transient Absorption Spectra. Figure 6 shows the excited state absorption spectrum for complex I in $\mathrm{CH}_{3} \mathrm{CN}$ solution after excitation with an $8 \mathrm{~ns}$ pulse at $355 \mathrm{~nm}$ irradiation. There is a bleach of absorption band at $400 \mathrm{~nm}$ and new structured absorption with maxima centered at $350 \mathrm{~nm}$ and $600 \mathrm{~nm}$ consistent with formation of an MLCT ( Ru $\rightarrow$ phen) excited state [11].

3.5. Photochemistry. The complexes are stable in deaerated solutions in the absence of light. When solutions of complex II were subject to continuous photolysis, the resulting optical spectral changes were consistent with the substitution of only one pyrazine molecule by a solvent molecule (1) and (2)

$$
\begin{aligned}
& \text { cis- }\left[\mathrm{Ru}(\text { phen })_{2}(\mathrm{pz})_{2}\right]^{2+}+\mathrm{CH}_{3} \mathrm{CN} \\
& \longrightarrow \text { cis- }\left[\mathrm{Ru}(\mathrm{phen})_{2}(\mathrm{pz})\left(\mathrm{CH}_{3} \mathrm{CN}\right)\right]^{2+}+\mathrm{pz} \\
& \text { cis- }\left[\mathrm{Ru}(\mathrm{phen})_{2}(\mathrm{pz})\left(\mathrm{CH}_{3} \mathrm{CN}\right)\right]^{2+}+\mathrm{CH}_{3} \mathrm{CN} \\
& \longrightarrow \text { cis- }\left[\mathrm{Ru}(\text { phen })_{2}\left(\mathrm{CH}_{3} \mathrm{CN}\right)_{2}\right]^{2+}
\end{aligned}
$$

For example, Figure 7 illustrates the spectral changes seen when an acetonitrile solution of complex $\mathbf{I}(0.22 \mathrm{mM})$ was irradiated at $\lambda_{\text {irr }}=420 \mathrm{~nm}, \mathbf{I}_{0}=1.27 \times 10^{-8}$ einstein $\mathrm{s}^{-1}$. The spectra show a progressive depletion of the characteristic absorption band at $400 \mathrm{~nm}$ concomitant with formation of two broad shoulders at 385 and $422 \mathrm{~nm}$, in accordance with the formation of complex $\mathrm{Ru}(\mathrm{phen})_{2}\left(\mathrm{CH}_{3} \mathrm{CN}\right)_{2}$ [12]. For complexes I and II, exhaustive photolysis leads to the same final stable spectrum assigned to the monosolvated complex.

3.6. Photoinduced Electron Transfer Reactions. Figure 8 shows the UV-vis spectral changes of the thermal reaction $\left(\mathrm{MV}^{\bullet+} \rightarrow \mathrm{MV}^{2+}\right)$ of a solution containing complex III and $\mathrm{MV}^{2+}$ (methyl viologen) in pure water immediately after $10 \mathrm{~s}$ continuous irradiation at $355 \mathrm{~nm}$ light. Before irradiation, the absorption spectrum of the mixture shows the characteristic absorption of starting complex $\left(\lambda_{\max }=380 \mathrm{~nm}\right)$. A broad absorption band with maximum near $605 \mathrm{~nm}$ and a peak at $394 \mathrm{~nm}$ appeared just after irradiation. These new absorptions match the methyl viologen radical $\left(\mathrm{MV}^{\bullet+}\right)$ absorption spectrum [13].

The photoinduced electron transfer reactions for complexes I and II did not occur, since in the UV-vis spectra was not observed any $\mathrm{MV}^{\bullet+}$ characteristic band even after exhaustive photolysis. These results show that the intermolecular photoinduced electron transfer reaction is activated in water only in certain conditions. The presence of $\mathrm{Ru}(\mathrm{II})$ unit inhibits the $\mathrm{MV}^{2+}$ reduction.

\section{References}

[1] I. De Aguiar, S. D. Inglez, F. C. A. Lima et al., "Photochemical reactions of $f a c-\left[\mathrm{Mn}(\mathrm{CO})_{3} \text { (phen)imidazole }\right]^{+}$: evidence for long-lived radical species intermediates," Inorganic Chemistry, vol. 47, no. 24, pp. 11519-11526, 2008.

[2] V. C. Nogueira, C. Longo, A. F. Nogueira, M. A. Soto-Oviedo, and M. A. D. Paoli, "Solid-state dye-sensitized solar cell: improved performance and stability using a plasticized polymer electrolyte," Journal of Photochemistry and Photobiology A, vol. 181, no. 2-3, pp. 226-232, 2006.

[3] B. P. Sullivan, D. J. Salmon, and T. J. Meyer, "Mixed phosphine 2,2' -bipyridine complexes of ruthenium," Inorganic Chemistry, vol. 17, no. 12, pp. 3334-3341, 1978.

[4] E. C. Johnson, B. P. Sullivan, D. J. Salmon, S. A. Adeyemi, and T. J. Meyer, "Synthesis and properties of the chloro-bridged dimer $\left[(\text { bpy })_{2} \mathrm{RuCl}\right]_{2}^{2+}$ and its transient $3+$ mixed-valence ion," Inorganic Chemistry, vol. 17, no. 8, pp. 2211-2215, 1978.

[5] P. Bonneson, J. L. Walsh, W. T. Pennington, A. W. Cordes, and B. Durham, "Six-coordinate complexes with 1,10-phenanthroline ligands in the trans configuration. Preparation of trans-bis(1,10-phenanthroline)ruthenium(II) complexes and crystal structure of trans-bis(1,10-phenanthroline)bis(pyridine)ruthenium(II) hexafluorophosphate," Inorganic Chemistry, vol. 22, no. 12, pp. 1761-1765, 1983.

[6] R. M. Carlos, I. Ap. Carlos, B. S. Lima Neto, and M. G. Neumann, "Spectroscopic and electrochemical properties of $\left[\mathrm{Mn}(\right.$ phen $)(\mathrm{CO})_{3}$ (imidazole) $]\left(\mathrm{SO}_{3} \mathrm{CF}_{3}\right)$ complexes," Inorganica Chimica Acta, vol. 299, no. 2, pp. 231-237, 2000.

[7] L. A. Berben, M. C. Faia, N. R. M. Crawford, and J. R. Long, "Angle-dependent electronic effects in 4,4'-bipyridine-bridged $\mathrm{Ru}_{3}$ triangle and $\mathrm{Ru}_{4}$ square complexes," Inorganic Chemistry, vol. 45, no. 16, pp. 6378-6386, 2006.

[8] K. Kalyanasundaram, Photochemistry of Polypiridyne and Porphyrin Complexes, Academic Press, London, UK, 1992.

[9] C.-T. Lin, W. Böttcher, M. Chou, C. Creutz, and N. Sutin, "Mechanism of the quenching of the emission of substituted polypyridineruthenium(II) complexes by iron(III), 
chromium(III), and europium(III) ions," Journal of the American Chemical Society, vol. 98, no. 21, pp. 6536-6544, 1976.

[10] F. Barigelletti, A. Juris, V. Balzani, P. Belser, and A. Von Zelewsky, "Influence of the ligand structure on the electrochemical and spectroscopic properties of ruthenium(II)polypyridine complexes," Inorganic Chemistry, vol. 26, no. 24, pp. 4115-4119, 1987.

[11] C. Creutz, M. Chou, T. L. Netzel, M. Okumura, and N. Sutin, "Lifetimes, spectra, and quenching of the excited states of polypyridine complexes of iron(II), ruthenium(II), and osmium(II)," Journal of the American Chemical Society, vol. 102, no. 4, pp. 1309-1319, 1980.

[12] P. Bonneson, J. L. Walsh, W. T. Pennington, A. W. Cordes, and B. Durham, "Six-coordinate complexes with 1,10-phenanthroline ligands in the trans configuration. Preparation of trans-bis(1,10-phenanthroline)ruthenium(II) complexes and crystal structure of trans-bis(1,10-phenanthroline)bis(pyridine)ruthenium(II) hexafluorophosphate," Inorganic Chemistry, vol. 22, no. 12, pp. 1761-1765, 1983.

[13] T. Watanabe and K. Honda, "Measurement of the extinction coefficient of the methyl viologen cation radical and the efficiency of its formation by semiconductor photocatalysis," Journal of Physical Chemistry, vol. 86, no. 14, pp. 2617-2619, 1982. 

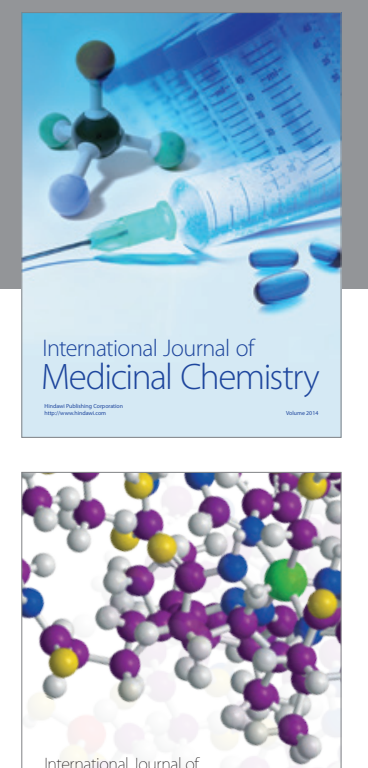

\section{Carbohydrate} Chemistry

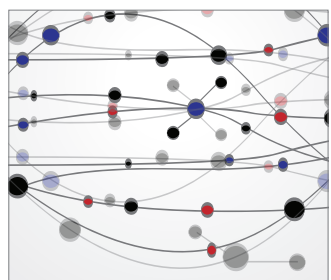

The Scientific World Journal
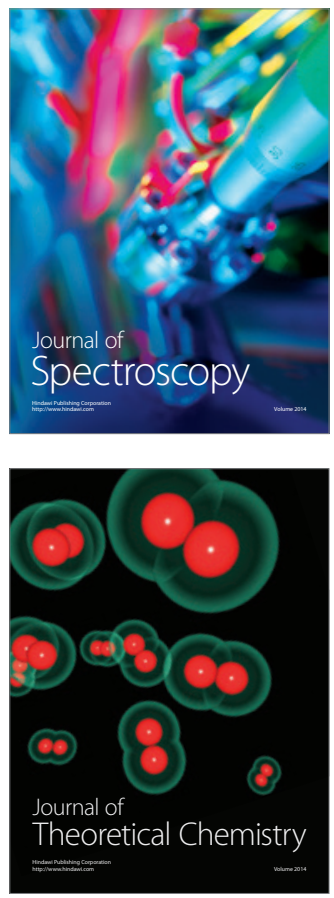
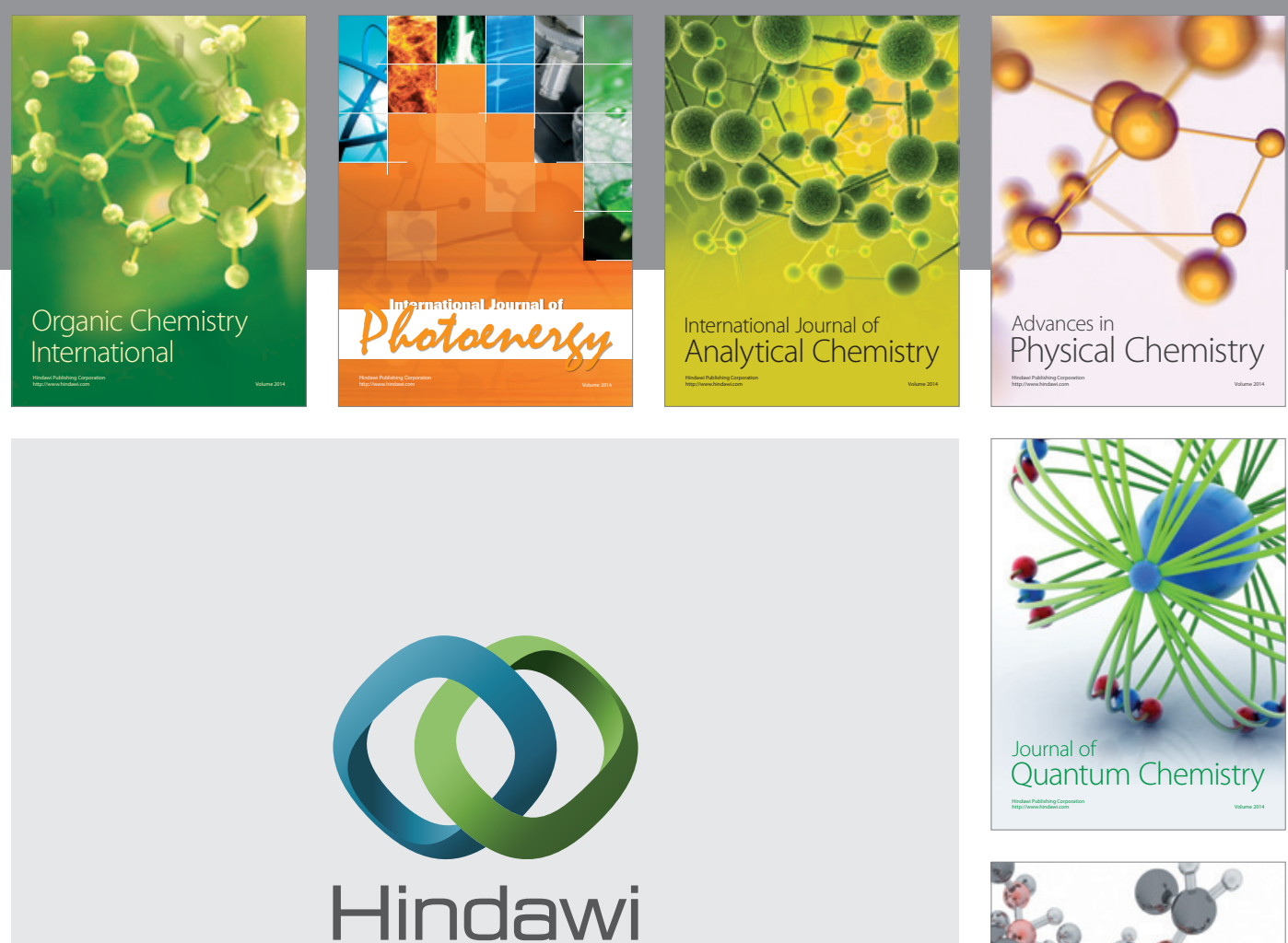

Submit your manuscripts at

http://www.hindawi.com

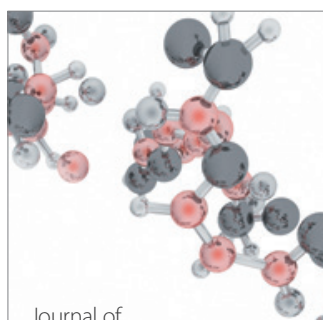

Analytical Methods

in Chemistry

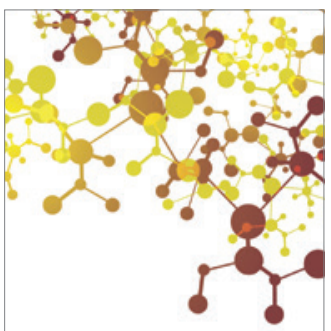

Journal of

Applied Chemistry

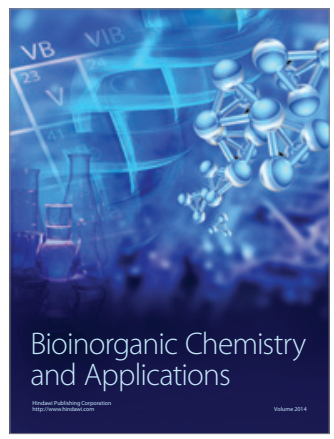

Inorganic Chemistry
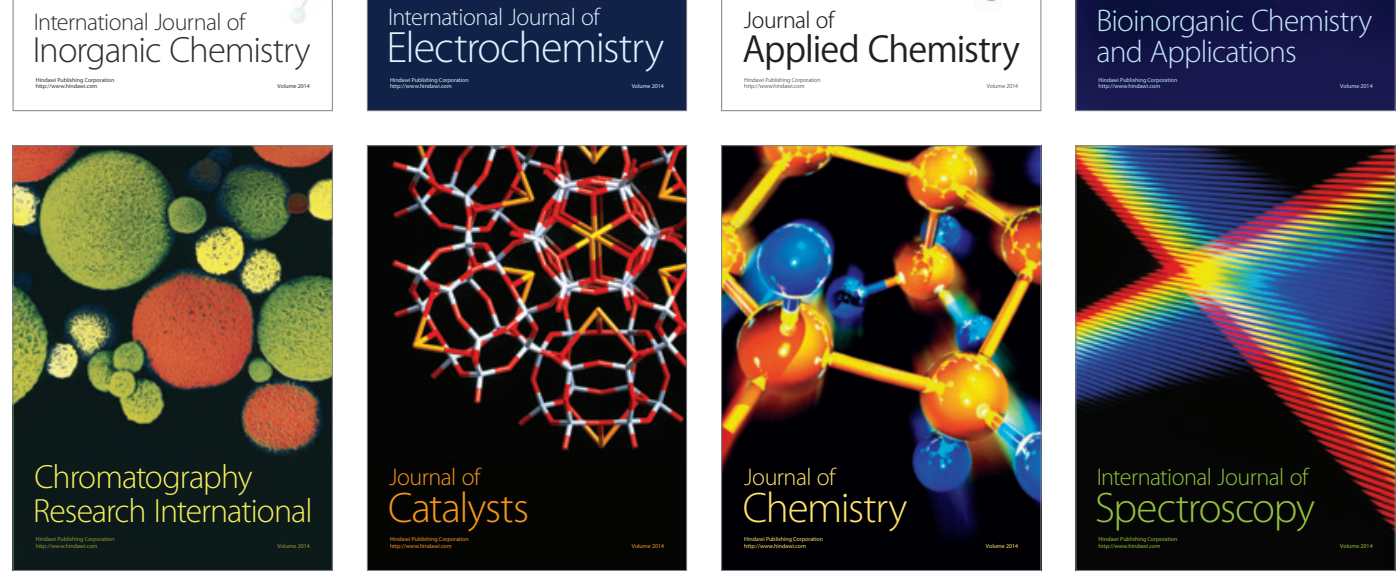